\title{
The Effect of Training on Work Performance and Career Development: The Role of Motivation as Intervening Variable
}

\author{
Dewi Rama Niati ${ }^{1}$, Zulkifli Musannip Efendi Siregar ${ }^{2}$, Yudi Prayoga ${ }^{3}$ \\ ${ }^{1,2,3}$ Universitas Labuhanbatu, Indonesia \\ zulkiflimusannipefendi@gmail.com
}

\begin{abstract}
This study aims to determine the effect of training on work performance and career development by mediating work motivation. Respondents in this study were employees of PT. Asam Jawa in South Labuhanbatu Regency, amounting to 135 employees. Collecting data in this study using a questionnaire. The process of distributing questionnaires was carried out via online (Google form). The collected data is processed using path analysis using Amos Software Version 23. The results showed that training and motivation can improve job performance. Training, motivation, and job performance can improve career development of employees at work. It is recommended to improve training program, motivation and work performance of employess. For further research, we suggest to increase the population and variables in order to get better results.
\end{abstract}

Keywords

training, motivation; work performance; carier development

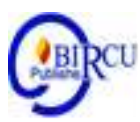

\section{Introduction}

Every organization must have a goal to be achieved. To achieve this goal, the company must be able to maintain its existence in business competition, the company cannot rely solely on the sophistication of existing technology and infrastructure without being supported by reliable human resources. To form reliable human resources in a company starts from the recruitment process, selection, classification, placement of employees according to the abilities, expertise, skills of these employees to career development. Career development is expected by every employee to motivate them to work well (Afiyati, 2018). Career development can be concluded as a continuous process in which the individual through individual effort to realize the goal of customized career planning and organizational conditions (Priyono; et al., 2016).

Career development is a process of increasing individual employability to achieve the desired career (Adnyani \& Dewi, 2019). Career development is not only to provide opportunities for employees to obtain higher career paths but to provide more responsibility and appreciation for the efforts made by employees (Afiyati, 2018).

In addition to organizational factors in the form of awards given by the company itself, training also affects career development. Mangkuprawira and Hubeis (in Hamali, 2016: 62) also states that training for employees is a process that teaches certain knowledge and skills and attitudes so that employees are more skilled and able to carry out their responsibilities better, in accordance with work standards (Marini Zakiyatul Umi, 2018). However, the lack of training and employee development opportunities is likely to be the cause of problems in employee career development (E. R. Putri, 2018).

One way to develop the performance possessed by employees in the company is the holding of a training program in which the implemented program is made according to the needs of the company (Triasmoko et al., 2014). TrainingTraining is one of the most important aspects in employee career development. This is evidenced by the findings of 
previous studies conducted by Saranani (2015), who found that training has an effect that is directly proportional to career development. This is in accordance with the research conducted by candra (2016) It was found that training had a positive and significant impact on career development. This is also confirmed by research conducted by Muis (2009), which revealed that the training variable had a positive and significant influence on career development variables (I Kadek Suadnyana, 2018).

\section{Review of Literature}

\subsection{Work Performance}

High employee performance will make it easier for employees to get the opportunity to be promoted to higher positions. Work performance is the result of a person's effort or seriousness in carrying out a job entrusted to him with his skills, experience and sincerity in accordance with the responsibilities that have been given to him (Garnida, 2017). Job performance is a result of work that has been achieved by a person in carrying out tasks that have been assigned to him based on skills, experience and sincerity and time (Hasibuan, 2014 in Sumenda1 et al., 2018). Adnyani \& Dewi, (2019) cited that job performance is a skill possessed by an employee to perform various jobs related to job needs

\subsection{Training}

Training is a process to shape and equip employees by adding their skills, abilities, knowledge and behavior, so that work can be completed more quickly, effectively and can be done rationally (Ichsan, 2020). In a narrow sense, by being given training, employees will get specific knowledge and be able to train skills that can later be used in work. (Saputra, 2017 in Adnyani \& Dewi, 2019). According to Mangkunegara, 2017 (in Jumawan \& Mora, 2018) explained that there are several dimensions and indicators in training. The training indicators include instructors, participants, materials, and objectives in the training. (Triasmoko et al., 2014) conclude that training is an activity process to teach employees such as skills, attitudes, discipline and provide skills according to the field of work that the employee will do.

\subsection{Carier Development}

Career development is a process of increasing individual employability achieved in order to realize the desired career. Sufficient work experience is required for employees, in order to provide job satisfaction to each employee which will have an effect on improving their performance (Adnyani \& Dewi, 2019). Therefore, every employee must be given the opportunity to develop their abilities and career and are expected to provide the best results for the company. Career development is an employment activity that helps employees plan their future careers in the company so that the company and the employees concerned can develop themselves optimally (Jumawan \& Mora, 2018). Career development is a step that can be used by companies to maintain and increase employee productivity and to prepare for an employee's future career (Cederyana, et al., 2018 in Winda Annisa Putri, 2019).

\subsection{Motivation}

Motivation is an awarding motif process that make employees to be working in such a way that the purpose of efficiently and effectively can be achieved several important factors that affect the motivation was personal needs, goals and perceptions of the individuals or groups and how to fulfill the needs, goals and perceptions (Priyono; et al., 2016). 
In order to increase productivity, motivation is needed to maintain and maintain employee perceptions to be more responsive to the work environment (Kamidin M, 2019). Motivation is the drive that moves employees to improve their performance so that they can achieve and achieve the goals set by the company (Afiyati, 2018). Motivation is also a force, both from within and from outside that can encourage a person to achieve the desired goals (Harahap \& Khair, 2019).

\subsection{Hypothesis Development}

a. The Relationship between Training on Motivation

According to Raharjo et al., (2014) said that training has a close relationship with motivation. The provision of training affects employee motivation, because after participating in the training, employees have skills and are skilled in doing tasks given by the agency with a heavier task weight, so that employee attitudes are better at accepting tasks and are enthusiastic in doing tasks. Cheema, Shujaat and Alam (2014) states that training can motivate workers to commitment and that motivation will lead to higher retention (in Darmawan et al., 2017).

\section{b. The Relatinship between Training and Motivation on Job Performance}

The training method has a significant effect on employee performance. Training material has a significant influence on employee performance. Training instructors have a significant influence on employee performance. Work motivation has a significant effect on performance (Raharjo et al., 2014) the research conducted by Hasanah (2010) found that training has an effect on job performancekerja (in Ratnasari, 2013). Research conducted by Caroline and Susan (2014) shows that education and training have an effect on employee work performance at Kenya State University and work performance has a positive influence on employee performance (in Pangestuti, 2019). The results of other studies also show an influence between training and employee performance (Triasmoko et al., 2014).

Research conducted by Aldi \& Susanti, (2019) that motivation, supervision and work discipline have a positive and significant effect on work performance. The results of previous research by Eka Suryaningsih Wardani (2009) stated that there was an influence between motivations on employee work performance at PT. Generation of Java-Bali Generation units (in Tanjung, 2015).

\section{c. The Relationship between Training, Motivation and Job Performance on Career Development}

Research conducted by Azmi et al (2009), Sriwidodo and Haryanto (2010), Nuzhat, Aamer and Roa (2013) stated that work performance affects employee career development (in Pangestuti, 2019). Job performance is very important in an employee's career path. Rational and objectively applied performance appraisal is tied to two interests, namely the interests of employees and the interests of the organization (Ibnu et al., 2015). Research conducted by Pradnyawati (2017) found that training has a positive and significant effect on career development. Triharyanto (2014) stated that training has a positive and significant effect on career development (in Adnyani \& Dewi, 2019c). Triharyanto (2014) found that work motivation and significant effect on the career development (in Yudasmara et al., 2017). 
Based on several literature reviews that have been described previously, a conceptual framework can be described as shown in Figure I below.

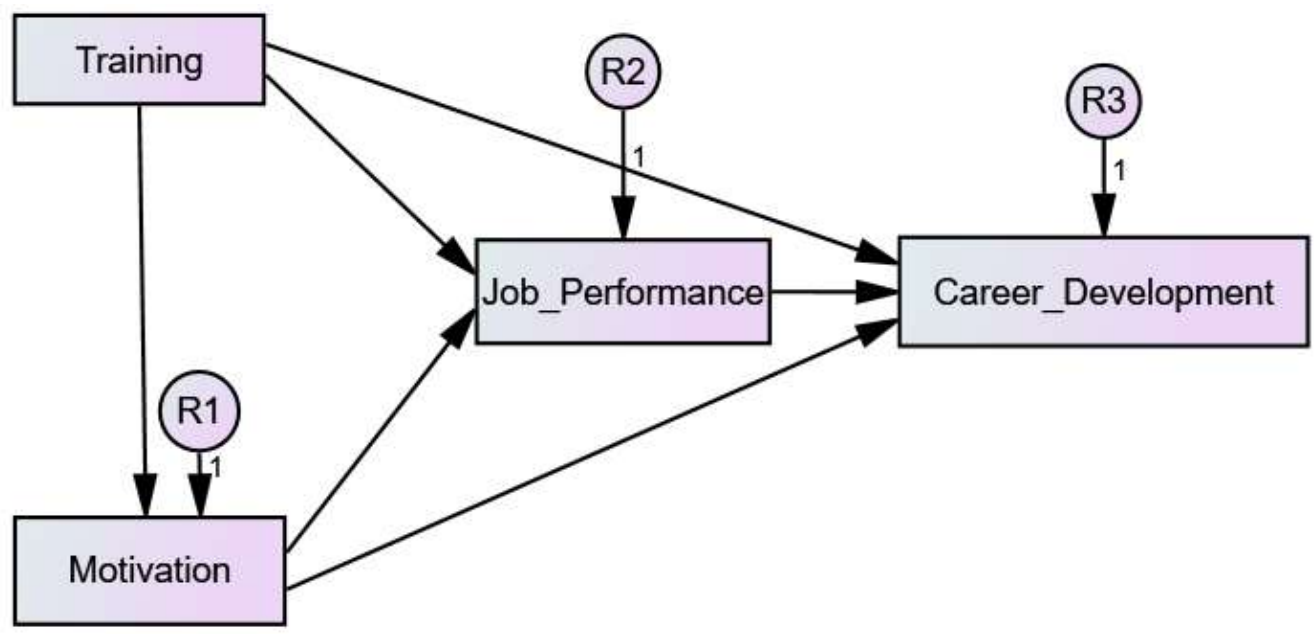

Figure 1. Conceptual Framework

\section{Research Methods}

This research was conducted di PT. Asam Jawa which is located in South Labuhanbatu Regency. In this study the population studied were all permanent employees at PT. Asam Jawa, amounting to 135 employees. The research method is carried out with a quantitative approach. Data were analyzed using the help of IBM SPSS Amos software version 23. Collecting data in this study using a questionnaire. The process of distributing questionnaires was carried out via online (Google form). The variables in this study consisted of four variables, namely training, work performance, career development and motivation.

The training was adopted from Mangkunegara, 2017 (in Pangestika et al., 2019) using five statement items for example, "the training material provided is complete and can be understood easily". Job performance was adopted from Sutrisno, 2014 (in Mashar, 2015) with five statement items (for example, "able to complete work effectively and efficiently"). Career development was adopted from Siagian, 2015 (in Jumawan \& Mora, 2018) with a five-item statement (for example, "getting fair treatment in the current career system"). Motivation was adopted from Afriska, 2017 (in W. A. Putri \& Frianto, 2019) as many as five statement items (for example, "trying to excel in every given job"). The measurement scale is carried out using a Likert scale, namely 1-5 (1: strongly disagree, 2 : disagree, 3: neutral, 4: agree, 5: strongly agree).

\section{Results and Discussion}

\subsection{Result}

\section{a Normality Testing}

The normality test aims to test whether the data is normally distributed or not. A good regression model is a normal or near normal distribution. The results of the normality test as shown in Table 1 indicate that C.R. amounting to 1.017. This shows that there are data that are normally distributed. For more details, see Table 1 below: 
Table 1. Normality Testing

\begin{tabular}{|l|rrrrrr|}
\hline & min & Max & skew & c.r. & kurtosis & c.r. \\
\hline Training & 12,000 & 20,000 &,- 174 &,- 696 &,- 621 & $-1,241$ \\
Motivation & 9,000 & 15,000 &,- 381 & $-1,522$ &,- 674 & $-1,347$ \\
Job Performance & 12,000 & 20,000 &,- 038 &,- 151 &,- 927 & $-1,854$ \\
Career Development & 15,000 & 25,000 &,- 307 & $-1,226$ &,- 716 & $-1,433$ \\
Multivariate & & & & & 1,438 & 1,017 \\
\hline
\end{tabular}

\section{b. Hypothesis Testing}

This study has six hypotheses which are tested using path analysis techniques. Path analysis is a direct development of multiple regression forms in order to determine the direct or indirect effect of a set of independent variables on the related variables. Hypothesis testing is performed using the P-value with a significance level of 0.05 . The Pvalue in the IBM SPSS AMOS version 23 program is the Critical Ratio (C.R.) value. If the value of Critical Ratio (C.R.) $>1.96$ or the probability value $(\mathrm{P})<0.05$ then $\mathrm{H} 0$ is rejected (the research hypothesis is accepted).

Table 2. Hypothesis Testing

\begin{tabular}{|c|c|c|c|c|c|c|c|}
\hline & & & Estimate & S.E. & C.R. & $\mathrm{P}$ & Decision \\
\hline Motivation & $<--$ & Training & ,538 & ,070 & 7,650 & $* * *$ & Accepted \\
\hline Job Performance & $<---$ & Training & 678 & 079 & 8,576 & $* * *$ & Accepted \\
\hline Job Performance & $<---$ & Motivation & ,337 & ,091 & 3,716 & $* * *$ & Accepted \\
\hline Career Development & $<---$ & $\begin{array}{l}\text { Job } \\
\text { Performance }\end{array}$ & , 130 & ,064 & 2,028 & ,043 & Accepted \\
\hline Career Development & $<---$ & Training & , 132 & ,066 & 1,998 & ,046 & Accepted \\
\hline Pengembangan_Karir & $<---$ & Motivasi & 1,364 & ,061 & 22,405 & $* * *$ & Accepted \\
\hline
\end{tabular}

The results of hypothesis testing can be explained as follows:

\section{Hypothesis Test 1}

The first hypothesis test is that there is a positive and significant influence between training on motivation. The results of this study indicate that the $t$ value (C.R.) is obtained of 7,650> 1.96 and has a P-value of $0,000<0.05$. It means that $\mathrm{H} 0$ is rejected and $\mathrm{Ha}$ is accepted, this shows that there is a positive and significant influence between training on career development.

\section{Hypothesis Test 2}

The second hypothesis test is that there is a positive and significant influence between training on work performance. The results of this study indicate that the t value (C.R.) is 8,576> 1.96 and has a P-value of $0,000<0.05$. It means that $\mathrm{H} 0$ is rejected and Ha is accepted, this shows that there is a positive and significant effect of training on work performance.

\section{Hypothesis Test 3}

The third hypothesis test is that there is a positive and significant influence between motivations on work performance. The results of this study indicate that the $t$ value (C.R.) is obtained of 3.716> 1.96 and has a P-value of $0.000<0.05$. It means that $\mathrm{H} 0$ is rejected 
and $\mathrm{Ha}$ is accepted, this shows that there is a positive and significant influence of motivation on work performance.

\section{Hypothesis Test 4}

The fourth hypothesis test is that there is a positive and significant influence between job performances on career development. The results of this study indicate that the calculated t value (C.R.) is 2.028> 1.96 and the P-value is $0.043<0.05$. It means that $\mathrm{HO}$ is rejected and $\mathrm{Ha}$ is accepted, this shows that there is a positive and significant effect of work performance on career development.

\section{Hypothesis Test 5}

The fifth hypothesis test is that there is a positive and significant influence between training on career development. The results of this study indicate that the t value (C.R.) is $1.998>1.96$ and the $\mathrm{P}$-value is $0.046<0.05$. It means that $\mathrm{H} 0$ is rejected and $\mathrm{Ha}$ is accepted, this shows that there is a positive and significant effect of training on career development.

\section{Hypothesis Test 6}

The sixth hypothesis test is that there is a positive and significant influence between motivations on career development. The results of this study indicate that the $t$ value (C.R.) is $22.405>1.96$ and the $\mathrm{P}$-value is $0.000<0.05$. It means that $\mathrm{H} 0$ is rejected and $\mathrm{Ha}$ is accepted, this shows that there is a positive and significant effect of training on career development.

\subsection{Discussion}

This study examines the effect of training on job performance and career development by mediating work motivation. This research deals with training, job performance, career development and motivation. This research was conducted at PT. Asam Jawa, South Labuhanbatu Regency using path analysis. Testing the first hypothesis shows that training affects motivation at PT. Asam Jawa significantly. This means that the more frequent training the superiors hold to employees, the more motivation the employees will have. Conversely, if training is rarely conducted by superiors, then employee motivation will also decrease. The findings of this study are in accordance with the findings of previous studies conducted by (Raharjo, Hamid \& Prasetya, 2014) and (Darmawan, Supartha \& Rahyuda, 2017) which shows that training has a significant effect on work motivation. This is also reinforced by research conducted by Zahra, Iram \& Naeem, 2014 (in Meidita, 2019) who concluded that training has an effect on motivation.

The second hypothesis testing shows that training significantly affects job performance. This means that if the training for employees is improved, the employee's work performance will also increase. Conversely, if the training is not improved, the resulting work performance will also decrease. The findings of this study are in accordance with the findings of previous studies conducted by Widyawati Mashar (2015) which shows that there is a significant influence between training and work performance (Awal \& Abrian, 2020).

The third hypothesis testing shows that motivation significantly influences job performance. This means that the higher the employee's motivation, the greater the level of work performance. Conversely, if the employee's motivation decreases, his work performance will also be lower. The findings of this study are in accordance with the 
findings of previous studies conducted by Priyono; et al., (2016) work motivation has a positive and significant effect on work performance. This finding is in line with research conducted by (Elisa \& Malawat, 2020) stated that work motivation has a positive and significant effect on work performance.

The fourth hypothesis testing shows that job performance significantly influences career development. This means that the better the work performance of the employees, the greater the opportunity for career development. Conversely, if the employee's work performance is poor, the opportunity for career development is also getting smaller. The findings of this study are in accordance with the findings of previous studies conducted by Gayatri \& Sriathi, (2020) that there is a positive and significant influence between work performance on career development.

Testing the fifth hypothesis shows that training significantly affects career development. This means that if employee training is carried out, then their career development will be even better. Conversely, if employee training is not carried out, their career development will also get worse. The findings of this study are in accordance with the findings of previous studies conducted by Adnyani (2019) and (Gayatri \& Sriathi, 2020) which states that training has a positive and significant effect on career development. Motivation is also proven to have a positive and significant effect on career development. This means that the higher the motivation of an employee, the better his career development will be. Conversely, if an employee's motivation decreases, his career will not develop either. The findings of this study are in accordance with the findings of previous studies conducted by Agustina, (2020) in his research resulted in the conclusion that work motivation has a positive and significant impact on career development.

\section{Conclusion}

Based on the results of the analysis, it can be seen that training can improve employee work performance which in turn can improve the employee's career development as well. Companies that often conduct training for employees will increase employee work performance and employees will be more motivated to work so that company goals can be achieved. From the above conclusions and in order to improve employee career development, it is advisable for further research that wants to investigate further about training on work performance and career development by mediating work motivation, which should be able to expand the population and variables so that it can get better results.

\section{References}

Adnyani, N. L. P. R., \& Dewi, A. A. S. K. (2019a). Pengaruh Pengalaman Kerja, Prestasi Kerja Dan Pelatihan Terhadap Pengembangan Karier Karyawan. E-Jurnal Manajemen Universitas Udayana, 4073. https://doi.org/10.24843/ejmunud.2019.v08.i07.p03

Afiyati, E. M. (2018). Pengaruh Pengembangan Karir, Motivasi Kerja, Dan Disiplin Kerja Terhadap Kinerja Karyawan Bank Syariah Mandiri Cabang Surakarta. Journal of Materials Processing Technology, 1(1), 1-142.

Agustina, R. (2020). Pengaruh Motivasi Kerja terhadap Pengembangan Karir Perawat di Ruang Rawat Inap dan Rawat Jalan.Skripsi : Universitas Citra Bangsa Kupang. 
Aldi, Y., \& Susanti, F. (2019). Pengaruh Stress Kerja dan Motivasi Kerja terhadap Prestasi Kerja Karyawan pada PT. Frisian Flag Indonesia Wilayah Padang. 1-11. https://doi.org/10.31227/osf.io/et4rn

Awal, A., \& Abrian, Y. (2020). Pengaruh Pelatihan terhadap Prestasi Kerja Karyawan di The Axana Hotel Padang. Jurnal Kajian Pariwisata Dan Bisnis Perhotelan, 7-16. https://doi.org/10.24036/jpk/vol10-iss1/506

Darmawan, Y. Y., Supartha, W. G., \& Rahyuda, A. G. (2017). Pengaruh Pelatihan terhadap Motivasi Kerja dan Kinerja di Prama Sanur Beach-Bali. 6(3), 1265-1290.

Elisa, \& Malawat, S. (2020). Pengaruh Motivasi Kerja, Disiplin dan Kepuasan Kerja terhadap Prestasi Kerja Pegawai pada Dinas Kependudukan dan Pencatatan Sipil di Kabupaten Batu Bara. 1-10.

Garnida, D. (2017). Pengaruh Pendidikan, Pengalaman Kerja dan Prestasi Kerja terhadap Pengembangan Karir Pegawai di Dinas Pekerjaan Umum Kabupaten Kutai Timur. EJournal Pemerintahan Integrattif, 5(4), 626-635.

Gayatri, I. A. D. S., \& Sriathi, A. A. A. (2020). Pengaruh Pengalaman Kerja, Prestasi Kerja serta Pendidikan dan Pelatihan terhadap Pengembangan Karir Karyawan. E-Jurnal Manajemen Universitas Udayana, 9(4), 1358-1378. https://doi.org/10.24843/ejmunud.2020.v09.i04.p07

Harahap, D. S., \& Khair, H. (2019). Pengaruh Kepemimpinan Dan Kompensasi Terhadap Kepuasan Kerja Melalui Motivasi Kerja. Maneggio: Jurnal Ilmiah Magister Manajemen, 2(1), 69-88. https://doi.org/10.30596/maneggio.v2i1.3404

I Kadek Suadnyana, I. W. G. S. (2018). Pengaruh Penilaian Kinerja, Pengalaman Kerja, Dan Pelatihan Terhadap Pengembangan Karir Karyawan. E-Jurnal Manajemen Universitas Udayana, 7(4), 1950-1978.

Ibnu, S., Ratna, K. A., \& Paranoan. (2015). Pengaruh Motivasi Terhadap Prestasi Kerja Pada Pegawai Dinas Bina Marga Dan Pengairan Kota Samarinda. Jurnal Administrasi Reform, 3(1), 210-221.

Ichsan, R. N. (2020). Pengaruh Pelatihan terhadap Prestasi Kerja Karyawan pada PDAM Tirtanadi Cabang Padang Bulan Medan. Jurnal Ilmiah METADATA, 2(1), 71-77.

Jumawan, J., \& Mora, M. T. (2018a). Pengaruh Pelatihan Dan Pengembangan Karier Terhadap Kinerja Karyawan Perusahaan Korporasi. Jurnal Riset Manajemen Dan Bisnis (JRMB) Fakultas Ekonomi UNIAT, 3(3), 343-352. https://doi.org/10.36226/jrmb.v3i3.153

Jumawan, \& Mora, M. T. (2018b). Pengaruh Pelatihan dan Pengembangan Karier terhadap Kinerja Karyawan Perusahaan Korporasi. Jurnal Riset Manajemen Dan Bisnis (JRMB) Fakultas Ekonomi UNIAT, 3(3), 343-352. https://doi.org/10.36226/jrmb.v3i3.153

Marini Zakiyatul Umi, I. N. (2018). Pengaruh Pelatihan Terhadap Kinerja Karyawan: Studi Pada Pt . Mitra Solusi Telematika ( Mst ) Jakarta. 5(1), 1123-1129.

Mashar, W. (2015). Pengaruh Pelatihan terhadap Prestasi Kerja Pegawai pada Inspektorat Kabupaten Rokan Hulu. Pengaruh Pelatihan Terhadap Prestasi Kerja Pegawai Pada Inspektorat Kabupaten Rokan Hulu, 1-13.

Meidita, A. (2019). Pengaruh Pelatihan dan Kompetensi terhadap Kepuasan Kerja Melalui Motivasi Kerja. Maneggio: Jurnal Ilmiah Magister Manajemen, 2(2), 1-12. https://doi.org/10.30596/maneggio.v2i2.3772

Pangestika, K. D., Astari, G. O., Silaban, M., \& Haitami, M. (2019). Pengaruh Pelatihan dan Disiplin terhadap Kinerja Karyawan Pada PT . Perkebunan Sumatera Utara. Jurnal Mutiara Manajemen, 4(1), 323-330. 
Pangestuti, D. C. (2019). Analisis Pengalaman Kerja, Kompetensi, Pendidikan, dan Pelatihan terhadap Pengembangan Karir dengan Intervening Prestasi Kerja. Jurnal Riset Manajemen Dan Bisnis (JRMB) Fakultas Ekonomi UNIAT, 4(1), 57-68. https://doi.org/10.36226/jrmb.v4i1.136

Priyono; Chandra, T., \& Ariana, S. (2016). Influence of work environment, motivation and career development on the work achievement on a timeless gift PT. Aligned sidoarjo. International Journal of Applied Business and Economic Research, 14(3), 2113-2131.

Putri, E. R. (2018). Pengaruh pengembangan karir dan motivasi terhadap kinerja karyawan lembaga kesehatan cuma-cuma dompet dhuafa (LKC DD). Skripsi : Fak.Ekonomi dan Bisnis Uin Jakarta.

Putri, W. A., \& Frianto, A. (2019). Pengaruh Pengembangan Karir terhadap Motivasi dan Dampaknya terhadap Kinerja Karyawan (Studi Kasus di PT. Barata Indonesia (PERSERO) Gresik. Jurnal Ilmu Manajemen, 7(2), 1-10.

Raharjo, R. P., Hamid, D., \& Prasetya. (2014). Pengaruh Pelatihan terhadap Motivasi Kerja dan Kinerja Pegawai (Studi Pada Pegawai Balai Besar Pelatihan Pertanian (BBPP) Ketindan-Lawang). Jurnal Administrasi Bisnis S1 Universitas Brawijaya, 15(2), 84788.

Ratnasari, S. L. (2013). Pengaruh Faktor-Faktor Pelatihan terhadap Prestasi Kerja Karyawan Departemen Produksi PT. X Batam. Buletin Studi Ekonomi, 18(1), 43-50.

Sumenda1, V., Kaunang2, M., \& Kumayas3, N. (2018). Prestasi Kerja Aparatur Sipil Negara Dalam Menunjang Promosi Jabatan Di Kabupaten Kepulauan Talaud. Jurnal Jurusan Ilmu Pemerintahan, Volome 1 N(1).

Tanjung, D. H. (2015). Pengaruh Disiplin Kerja dan Motivasi Kerja terhadap Prestasi Kerja Pegawai pada Dinas Sosisl dan Tenaga Kerja Kota Medan. Jurnal Ilmiah Manajemen Dan Bisnis, 15(01), 27-36.

Triasmoko, D., Mukzam, M. D., \& Nurtjahjono, G. E. (2014). Pengaruh Pelatihan Kerja terhadap Kinerja Karyawan (Penelitian pada Karyawan PT Pos Indonesia (Persero) Cabang Kota Kediri). Jurnal Administrasi Bisnis S1 Universitas Brawijaya, 12(1), 82871.

Winda Annisa Putri, A. F. (2019). Pengaruh Pengembangan Karier Terhadap Motivasi dan Dampaknya Terhadap Kinerja Karyawan (Studi Kasus di PT. Barata Indonesia (Persero) Gresik). Jurnal Ilmu Manajemen, 7(2), 1-10.

Yudasmara, K. K., Isharijadi, \& Murwani, J. (2017). Pengaruh Diklat dan Motivasi Kerja terhadap Pengembangan Karir Karyawan di PT. KAI Madiun. Forum Ilmiah Pendidikan Akuntansi 5(1), 605-621. 